\title{
Synthesis, Characterization, and Impregnation of Some Ionic Liquids on Polymer Membrane for Separation of Carbon Dioxide from Its Mixture with Methane
}

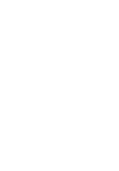

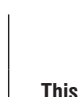

This work is licensed under a

Creative Commons Attribution 4.0 International License

\author{
T. T. L. Bui, ${ }^{a,{ }^{,}}$H. T. N. Uong, ${ }^{b, c, d}$ L. V. Nguyen, ${ }^{b}$ and N. C. Pham ${ }^{e}$ \\ ${ }^{a}$ Oil Refinery and Petrochemistry Department, Hanoi University of Mining \\ and Geology, 18-Vien, Duc Thang, Bac Tu Liem, Ha Noi, Viet Nam \\ 'Institute of Chemistry, Vietnam Academy of Sciences and Technology, \\ 18-Hoang Quoc Viet, Nghia Đo, Cau Giay, Ha Noi, Viet Nam \\ 'Institute of Science and Technology, Vietnam Academy \\ of Sciences and Technology, 18-Hoang Quoc Viet, Nghia Đo, \\ Cau Giay, Ha Noi, Viet Nam \\ ${ }^{\mathrm{d} C h e m i s t r y ~ D e p a r t m e n t, ~ U n i v e r s i t y ~ o f ~ M e d i c i n e ~ a n d ~ P h a r m a c y, ~}$ \\ 227 Hong Bang, Hochiminh City, Viet Nam \\ ${ }^{\mathrm{e} H i g h}$ School for Gifted Students, Ha Noi National \\ University of Education
}

doi: 10.15255/CABEQ.2017.1193

Original scientific paper

Received: July 10, 2017

Accepted: March 1, 2018

Some 1-alkyl-3-methylimidazolium-based ionic liquids were synthesized, characterized, and immobilized on membranes to form supported ionic liquid membranes. The supported ionic liquid membranes were characterized by SEM. The initial transmembrane pressures were investigated for each type of impregnated membrane. The $\mathrm{CO}_{2} / \mathrm{CH}_{4}$ single gas and mixed gas permeability $\left(\mathrm{CO}_{2}\right.$ and $\left.\mathrm{CH}_{4}\right)$ have been investigated. The results showed that the $\mathrm{CO}_{2} / \mathrm{CH}_{4}$ ideal selectivities and mixed gas selectivities reached 15.45 23.9 and $13.91-22.82$, respectively (equivalent to separation yields of $93.3-95.98 \%$ ). The 1-alkyl-3-methylimidazolium acetate impregnated membrane leads to a slightly lower $\mathrm{CO}_{2} / \mathrm{CH}_{4}$ selectivity, however, this ionic liquid is stable, free of halogen and has a low price. The impregnated membranes prepared from polyvinylidene fluoride are more stable than those from polyethersulfone support, and have a higher affinity for $\mathrm{CO}_{2}$ compared to other gas. The obtained high $\mathrm{CO}_{2} / \mathrm{CH}_{4}$ selectivities indicate that immobilized membranes can be used for $\mathrm{CO}_{2}$ separation processes.

Keywords:

ionic liquid, $\mathrm{CO}_{2} / \mathrm{CH}_{4}$ separation, membrane, supported ionic liquid membrane

\section{Introduction}

Much of the natural gas produced worldwide requires significant treatment because in some natural gas wells the content of $\mathrm{CO}_{2}$ up to $70 \%$ of the total gas volume can be observed. ${ }^{1,2} \mathrm{CO}_{2}$ separation is of critical economical importance because $\mathrm{CO}_{2}$ causes pipeline corrosion and decreases the calorific value of natural gas. ${ }^{3}$ The current US pipeline specifications require $\mathrm{CO}_{2}$ content to be below $2 \%$ by volume. ${ }^{1}$ The most frequently used methods in the $\mathrm{CO}_{2}$ separation technology include adsorption using solid adsorbents (carbon) or absorption and stripping using physical or chemical solvents (aqueous amines), separation using membrane, molecular sieve. ${ }^{4}$

Membrane separation is an emerging technology and has numerous advantages over adsorption

*Corresponding author: thuykhai2001@gmail.com and absorption methods, such as ease of operation, low operating and installation cost, small size, low weight, and low environmental impact..$^{5}$ Some kinds of membranes for $\mathrm{CO}_{2}$ separation have been currently commercialized, such as cellulose acetate, polyimide, polysulfone, polycarbonate, polyesterimide... However, membrane technology still has some disadvantages, since long-term stability of the flux and the membrane material is still not proved to be reliable and there is a trade-off between permeability and selectivity, in most cases polymers have high permeability with relatively low selectivity values. ${ }^{6,7}$

The application of supported liquid membranes (SLMs) for gas/vapor separations has been widely investigated over the last 20 years. ${ }^{8}$ In a SLM, the membrane pores are impregnated with a selected solvent, and permeation of the gas/vapor molecules occurs according to a solution-diffusion mass trans- 
fer mechanism. The gas separation using SLM combines the advantages of permeation and extraction; the selectivity of those membranes is higher than that of non-impregnated liquid membranes (conventional membranes) if appropriate solvents are selected. ${ }^{9}$ The permeability across supported liquid membranes is higher than when using solid membranes, because the diffusion of species in liquids is faster compared to the diffusion in solids. Even though SLMs are considered attractive for gas separations, their application in industry is still limited, mainly due to problems in their stability and longterm performance.

Ionic liquids (ILs) are organic salts that are liquid at room temperature, thermally stable and non-flammable, and have a negligible vapor pressure, and these properties make them ideal candidates as the separation medium for liquid membranes. ${ }^{10-14}$ Supported ionic liquid membranes (SILMs) are a new type of membrane system composed of ionic liquids (ILs) impregnated onto polymeric or inorganic supports. Their advantages in gas separation include the high solubility of $\mathrm{CO}_{2}$ in selected ILs, they are environmentally friendly and can effectively treat gases consisting of a wide range of $\mathrm{CO}_{2}$ amounts, and they can eliminate the problem of solvent evaporation and leaching that typically occur in SLMs due to the negligible vapor pressure and moderate high viscosity of ionic liquids, allowing for obtaining liquid membranes with high stability. ${ }^{15-23}$ Different types of ionic liquids were used to prepare SILPs and membranes were tested under a variety of conditions. Membrane separation performance was evaluated based on gas permeability and selectivity. $\mathrm{He} / \mathrm{CO}_{2}$ permeability and selectivity of SILPs based on hexyl methyl imidazolium were investigated at temperatures from $37^{\circ} \mathrm{C}$ to $125^{\circ} \mathrm{C}$ by Ilconich et al. The results showed that the $\mathrm{CO}_{2} / \mathrm{He}$ ideal selectivity increased from 8.65 to 4.61 at studied temperature $(72-80 \%$ selectivity). ${ }^{24}$ Hanioka et al. reported $\mathrm{CO}_{2}$ separation from a $\mathrm{CO}_{2} / \mathrm{CH}_{4}$ mixture using $\mathrm{N}$-aminopropyl and methylimidazolium based ionic liquids from $25{ }^{\circ} \mathrm{C}$ to $75^{\circ} \mathrm{C}$, the selectivity increased from 7.33 to $9 . .^{25}$ The permeability of groups of gases $\left(\mathrm{CO}_{2}, \mathrm{SO}_{2}\right)$ and $\left(\mathrm{N}_{2}, \mathrm{O}_{2}, \mathrm{CO}_{2}, \mathrm{CH}_{4}\right)$ has been investigated using different SILMs. ${ }^{26-31}$ The results showed that selectivity of $\mathrm{CO}_{2} /$ air, $\mathrm{SO}_{2} /$ air, $\mathrm{CO}_{2} / \mathrm{N}_{2}, \mathrm{CO}_{2} / \mathrm{CH}_{4}$, and $\mathrm{O}_{2} / \mathrm{N}_{2}$ reached $86-87 \%, 73-81 \%, 86-88 \%, 82-86 \%$, and $57-73 \%$, respectively. In order to increase membrane stability and selectivity, several kinds of composite membranes have been recently prepared from polymers and ionic liquids, and used for $\mathrm{CO}_{2}$ separation from hydrocarbon gases..$^{32-37}$

Promising results encourage further research in this field. This work attempts to focus on some aspects: synthesis and structural characterization of some ionic liquids, immobilization of synthesized ILs onto preselected polymer membranes, calculation of the amount of ionic liquid impregnated, evaluation of the filling extent of ionic liquids in the pores of membranes, determination of the change of the structural surface of SILMs after immobilization of ILs, effect of pressure on the working stability of SILMs, evaluation of permeability of the single gases and of mixed gas $\left(\mathrm{CO}_{2}\right.$ and $\left.\mathrm{CH}_{4}\right)$, selectivity of $\mathrm{CO}_{2} / \mathrm{CH}_{4}$ mixture, and the influence of ionic liquid structure and type of polymer membrances on properties of SILPs.

\section{Experimental}

\section{Materials}

\section{Polymeric porous membranes}

The supported ionic liquid membranes were prepared using three different polymeric porous membranes as supporting materials, with a similar pore size but with different chemical nature, made of polyvinylidene fluoride (PVDF), polyethersulfone (PES) and cellulose acetate (CA), provided by Sterlitech Company, USA. These membranes play the role of supporting material of ionic liquids, and are characterized by their high chemical resistance. The pore size, porosity, thickness, dimension of these membranes are summarized in Table 1.

\section{Chemicals}

Methyl imidiazole $99.5 \%, n$-butyl chloride $99.5 \%$, sodium tetrafluoroborate $\left(\mathrm{NaBF}_{4}\right)$ were provided by Merk Schuchardt OHG, Germany. Ethyl acetate $99.5 \%$, acetone $99.55 \%$, methanol $99 \%$, ethanol $99 \%$, dichloromethane $99.5 \%$, ammonium acetate $99 \%$ were provided by Guangdong Guanghua, China. They were used without further purification.

Pure gases $\mathrm{CO}_{2}, \mathrm{CH}_{4}, \mathrm{~N}_{2}$, and $\mathrm{CO}_{2} / \mathrm{CH}_{4}$ mixture (50:50 volume ratio, purity of $99.99 \%$ ) were provided by Cryotech Company, Vietnam.

\section{Synthesis of ionic liquids}

Synthesis of ionic liquids 1-n-butyl-3-methyl imidazolium tetrafluoroborate ([BMIM] $\left[\mathrm{BF}_{4}\right]$ ), 1-n-butyl-3-methyl imidazolium acetate

Table 1 -Properties of membranes

\begin{tabular}{c|c|c|c|c}
\hline Membrane & $\begin{array}{c}\text { Pore size } \\
(\mu \mathrm{m})\end{array}$ & $\begin{array}{c}\text { Porosity } \\
(\%)\end{array}$ & $\begin{array}{c}\text { Thickness, } l \\
(\mu \mathrm{m})\end{array}$ & $\begin{array}{c}\text { Diameter } d_{i} \\
(\mathrm{~mm})\end{array}$ \\
\hline PVDF & \multicolumn{4}{l}{} \\
PES & 0.2 & 80 & 150 & 47 \\
CA & & & & \\
\hline
\end{tabular}




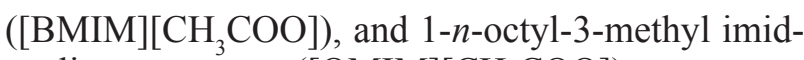
azolium acetate ([OMIM] $\left[\mathrm{CH}_{3} \mathrm{COO}\right]$ ) was performed in two steps.

In the first step, 1-methyl imidazolium and butyl chloride (or octyl chloride) were stirred at $70-75{ }^{\circ} \mathrm{C}$ for $100 \mathrm{~h}$ to form 1-butyl methyl imidazolium chloride ([BMIM]Cl) or 1-octyl methyl imidazolium chloride ([OMIM]Cl). The reaction mixture was extracted with ethyl acetate to remove unconverted reagents (yield $=98 \%$ ).

In the second step, ionic liquids [BMIM] $\left[\mathrm{CH}_{3} \mathrm{COO}\right] \quad\left([\mathrm{OMIM}]\left[\mathrm{CH}_{3} \mathrm{COO}\right]\right)$ and $[\mathrm{BMIM}]\left[\mathrm{BF}_{4}\right]$ were synthesized through the exchange reactions of $[\mathrm{BMIM}] \mathrm{Cl}([\mathrm{OMIM}] \mathrm{Cl})$ with $\mathrm{NH}_{4} \mathrm{CH}_{3} \mathrm{COO}$ or $\mathrm{NaBF}_{4}$ in acetone, stirred at room temperature for $48 \mathrm{~h}$. After the reaction was finished, inorganic salts and solvents were removed to obtain pure ionic liquids (yield $=90-93 \%$ ).

\section{Preparation of supported ionic liquid membranes (SILMs)}

The polymer membranes were placed to dry in a desiccator for several days and the original weights were determined. These membranes were then immersed in corresponding ionic liquids for 48 $\mathrm{h}$ to allow ionic liquids to penetrate and stabilize in the membranes. The excess ionic liquids on the membrane surface was cleaned with paper tissue. The amount of ILs immobilized in the membrane was determined gravimetrically by the difference in weights of the membrane before and after IL impregnation.

\section{Characterization of ionic liquids and membrane surface}

Infrared spectra (IR) of the prepared ionic liquids were measured using an IMPAC 410 spectrometer (Nicolet, USA). Mass spectra (MS) were measured by a LC/MS/MS-Xevo, API-ESI spectrometer in $\mathrm{MeOH}$. Nuclear magnetic resonance spectra ${ }^{1} \mathrm{H}-\mathrm{NMR}$ were measured using Bruker Advance in DMSO (for [BMIM] $\left[\mathrm{BF}_{4}\right]$ and [BMIM] $\left[\mathrm{CH}_{3} \mathrm{COO}\right]$ ), and in $\mathrm{D}_{2} \mathrm{O}$ (for [OMIM] $\left[\mathrm{CH}_{3} \mathrm{COO}\right]$ ) solutions. The surface characteristics of polymer membranes and SILPs were measured by a scanning electron microscope (SEM) S4800-NIHE $10 \mathrm{kV}$.

\section{Selection of suitable pressure difference between feed and permeate compartments}

The experiments were performed using a system as shown in Fig. 1. The stainless steel chamber consisted of feed and permeation compartments, which were separated by the supported ionic liquid membrane. The effective membrane area was 14.5 $\mathrm{cm}^{2}$. Firstly, the stability of supported ionic liquid membranes (SILMs) was investigated by gradually increasing the difference in pressure between the feed and permeation compartments. The supported ionic liquid membrane SILP to be investigated (9 kinds of SILPs) was installed within the two chamber compartments. The different amounts of $\mathrm{N}_{2}$ gas were filled in each compartment to form the pressure differences between them. The pressure difference increased from 0.4 to 1.9 bar. The pressures in both compartments were detected using two pressure gauges (Extech, USA) in order to evaluate the stability of SILMs by following the sudden change in pressure difference of the two compartments.

\section{Gas permeation experiments}

\section{Single gas permeability}

The permeability of pure gases $\left(\mathrm{CH}_{4}\right.$ and $\left.\mathrm{CO}_{2}\right)$ through the supported ionic liquid membranes was determined using the experimental apparatus (Fig. $1)$. The apparatus consisted of one feed compartment and one permeate compartment. Those two compartments were separated by the investigated membrane. The permeation cell was vacuumed and filled with investigated gas several times to ensure that only the investigated gas was filled in the system. The pure gas was introduced into the two compartments from bottle 1 . The initial transmembrane pressures (initial difference in pressure between the feed and the permeate compartments) were established at around 1 bar. The pressure change in both compartments over time was measured by two pressure gauges (Extech, USA).

\section{Gas mixture permeability}

The experimental procedure was similar to that used for measuring the single gas permeability. $\mathrm{CO}_{2} / \mathrm{CH}_{4}$ binary mixture (50/50 by volume) was ad-

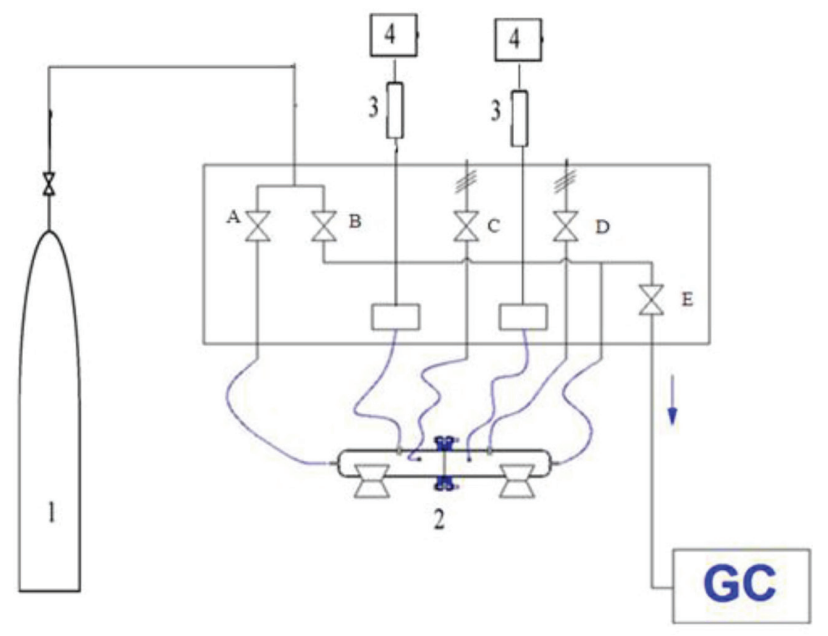

Fig. 1 - Experimental set-up for measuring permeability of SILMs (1: gas bottle, 2: Membrane test chamber, 3 and 4: $P=$ pressure gauges; $A, B, C$, and $D$ are gas valves) 
mitted into both compartments of the permeation cell. The gas mixture was pressurized into the feed and permeate compartments (an initial transmembrane pressure of around 1 bar), and the pressure change in both compartments over time was detected using two pressure gauges. Samples from the feed and permeate compartments were collected and analyzed by online GC (CHROMPACK) at the beginning and end of the experiment.

\section{Calculation methods}

Pore volume of polymer membranes is calculated according to eq. 1 .

$$
V_{\text {por }}=V_{\text {memb }} \cdot P_{\text {memb }}=\frac{\pi d_{i}^{2}}{4} \cdot l \cdot P_{\text {memb }}
$$

where, $V_{\text {por }}$ is pore volume of membrane, $V_{\text {memb }}$ is membrane porous volume, $P_{\text {memb }}$ is porosity of membrane, $d$ and $l$ are diameter $(\mathrm{cm})$, and thickness $(\mathrm{cm})$ of the membranes, respectively. Ionic liquid volume immobilized on polymer membranes is given by eq. 2 .

$$
V_{\mathrm{IL} / \mathrm{memb}}=\frac{m}{d}
$$

where $m$ and $d$ are immobilized ionic liquid weight (g), and density $\left(\mathrm{g} \mathrm{cm}^{-3}\right)$, respectively.

The permeability of a pure gas through a membrane is calculated according to the following equation: ${ }^{37}$

$$
\frac{1}{\beta} \ln \left(\frac{\left[p_{\text {feed }}-p_{\text {perm }}\right]_{0}}{\left[p_{\text {feed }}-p_{\text {perm }}\right]}\right)=\frac{1}{\beta} \ln \left(\frac{\Delta p_{0}}{\Delta p}\right)=P \frac{t}{l}
$$

where $p_{\text {feed }}$ and $p_{\text {perm }}$ are the pressures in the feed and permeate compartments $(\mathrm{Pa})$, respectively, $P$ is membrane permeability $\left(\mathrm{m}^{2} \mathrm{~s}^{-1}\right), t$ is time $(\mathrm{s})$, and $l$ is membrane thickness $(\mathrm{m})$. The geometric parameter $\beta\left(\mathrm{m}^{-1}\right)$ is characteristic of the geometry of the cell shown in Fig. 1, and is given by

$$
\beta=A \cdot\left(\frac{1}{V_{\text {feed }}}+\frac{1}{V_{\text {perm }}}\right)
$$

where $A$ is membrane area $\left(\mathrm{m}^{2}\right)$, and $V_{\text {feed }}$ and $V_{\text {perm }}$ are the volumes of the feed and permeate compartments $\left(\mathrm{m}^{3}\right)$, respectively. The ideal selectivity $\left(\alpha_{\mathrm{A} / \mathrm{B}}\right)$ can be determined by dividing the permeabilities of two different pure gases (A and B) (5).

$$
\alpha_{\mathrm{A} / \mathrm{B}}=\frac{P_{\mathrm{A}}}{P_{\mathrm{B}}}
$$

In the gas mixture experiments, the selectivity $\left(\alpha_{\mathrm{A} / \mathrm{B}}\right)$ is given by the equation:

$$
\alpha_{\mathrm{A} / \mathrm{B}}=\frac{y_{\mathrm{A}} / x_{\mathrm{A}}}{y_{\mathrm{B}} / x_{\mathrm{B}}}
$$

where $y_{\mathrm{A}}$ and $y_{\mathrm{B}}$ are mole fractions of gases $\mathrm{A}$ and $\mathrm{B}$ in the permeate compartment, respectively, and $x_{\mathrm{A}}$ and $x_{\mathrm{B}}$ are mole fractions of gases $\mathrm{A}$ and $\mathrm{B}$ in the feed compartment, respectively. The yield separation of gas A from a mixture with gas B is given by the eq. (7):

$$
H=\frac{\alpha_{\mathrm{A} / \mathrm{B}}}{\alpha_{\mathrm{A} / \mathrm{B}}+1}
$$

where $\alpha_{\mathrm{A} / \mathrm{B}}$ is selectivity.

\section{Results and discussion}

\section{Characterization of synthesized ionic liquids}

Ionic liquids were characterized by FT-IR, ${ }^{1} \mathrm{H}-\mathrm{NMR},{ }^{13} \mathrm{C}-\mathrm{NMR}$ and mass spectra. Structures of synthesized ionic liquids are given in Fig. 2.

\section{FTIR spectroscopy}

Bands of wave number $2905 \mathrm{~cm}^{-1}$ and 2869 $\mathrm{cm}^{-1}$ are the aliphatic asymmetric and symmetric $(\mathrm{C}-\mathrm{H})$ stretching vibrations. The bands of wave number of 1193 and $1112.93 \mathrm{~cm}^{-1}$ are due to the bending vibrations of methyl groups. The broad band in the range of $3124.68-3200.97 \mathrm{~cm}^{-1}$ is due to quaternary amine salt formation. The bands in the range $3157-3147 \mathrm{~cm}^{-1}$ come from $\mathrm{C}-\mathrm{H}$ bond in imidazolium ring. $\mathrm{C}=\mathrm{C}$ and $\mathrm{C}-\mathrm{C}$ stretching vibrations are shown by wave numbers $1640-1680$ $\mathrm{cm}^{-1}$ and $1558-1577 \mathrm{~cm}^{-1}$, respectively.

The band at wave numbers $832-886 \mathrm{~cm}^{-1}$ is due to the $\mathrm{C}-\mathrm{N}$ stretching vibration. The band in range $1100-1000 \mathrm{~cm}^{-1}$ in FT-IR spectra of [BMIM] $\left[\mathrm{BF}_{4}\right]$ is due to the presence of $\mathrm{B}-\mathrm{F}$ bond. The bands in the range of $1700-1730 \mathrm{~cm}^{-1}$ in FT-IR spectra of $[\mathrm{BMIM}]\left[\mathrm{CH}_{3} \mathrm{COO}\right]$ and $[\mathrm{OMIM}]\left[\mathrm{CH}_{3} \mathrm{COO}\right]$ have been assigned the $\mathrm{C}=\mathrm{O}$ stretching vibrations in ester groups.

\section{${ }^{1} \mathrm{H}-\mathrm{NMR}$ and ${ }^{13} \mathrm{C}-\mathrm{NMR}$ spectra}

Examples of numbering carbon and corresponding hydrogen atoms in ionic liquids are shown in Fig. 2.

${ }^{1} \mathrm{H}-\mathrm{NMR}$ data in $\mathrm{ppm}(\delta)$ from the internal standard (TMT, $0.0 \mathrm{ppm}$ ), chemical shift (multiplicity, integration), and ${ }^{13} \mathrm{C}$-NMR data in ppm $(\delta)$ from the internal standard (TMS, $0.0 \mathrm{ppm}$ ) were reported. The results of FT-IR and ${ }^{1} \mathrm{H}-\mathrm{NMR}$ analysis of $[\mathrm{BMIM}]\left[\left[\mathrm{BF}_{4}\right], \quad[\mathrm{BMIM}]\left[\mathrm{CH}_{3} \mathrm{COO}\right], \quad\right.$ and $[\mathrm{OMIM}]\left[\mathrm{CH}_{3} \mathrm{COO}\right]$ are given as follows:

1-n-butyl-3-methylimidazolium tetrafluoroborate [BMIM][FB ${ }_{4}$ : IR (KBr) $v / \mathrm{cm}^{-1} 3628,3164$, 2965, 2879, 1574, 1484, 1062, 484; ${ }^{1} \mathrm{H}-\mathrm{NMR}$ (500 MHz, DMSO-d) $\delta$ (ppm): 8.99 (s, 1H, CH), 7,70 (s, 
<smiles></smiles>

(a)<smiles>CCc1n(CCCO)cc[n+]1C</smiles>

(b)<smiles>CCCC=CCCCCn1cc[n+](C)c1CC</smiles>

(c)

Fig. 2 - Structure of synthesized ionic liquids (a: $[B M I M]\left[B F_{4}\right]$, b: [BMIM] $\left.\left[\mathrm{CH}_{3} \mathrm{COO}\right], \mathrm{c}:[\mathrm{OMIM}]\left[\mathrm{CH}_{3} \mathrm{COO}\right]\right)$

1H, CH), 7.63 (s, 1H, CH), $4.16(\mathrm{t}, 2 \mathrm{H}, J$ 7.0, $\left.\mathrm{N}-\mathrm{CH}_{2}\right), 3.85\left(\mathrm{~s}, 3 \mathrm{H}, \mathrm{N}-\mathrm{CH}_{3}\right), 1.79\left(\mathrm{~m}, 2 \mathrm{H}, \mathrm{CH}_{2}\right)$, $1.27\left(\mathrm{~m}, 2 \mathrm{H}, J 7.5, \mathrm{CH}_{2}\right), 0.89\left(\mathrm{t}, 3 \mathrm{H}, J 7.0, \mathrm{CH}_{3}\right)$.

\section{1-n-butyl-3-methylimidazolium acetate} [BMIM][CH COO]: IR ( $\mathrm{KBr}) v / \mathrm{cm}^{-1} 3433,3156$, 2958, 2880, 1641, 1567, 1464, 1170, 1120, 591,7, 466; ${ }^{1} \mathrm{H}-\mathrm{NMR}$ (500 MHz, DMSO-d) $\delta$ (ppm): 9.68 (s, 1H, CH), $7.95(\mathrm{~s}, 1 \mathrm{H}, \mathrm{CH}), 7.86(\mathrm{~s}, 1 \mathrm{H}, \mathrm{CH})$, $4.22(\mathrm{t}, J$ 7.5, 2H, N-CH $), 3.89\left(\mathrm{~s}, 3 \mathrm{H}, \mathrm{N}-\mathrm{CH}_{3}\right)$, $1.82\left(\mathrm{~s}, 3 \mathrm{H}, \mathrm{CH}_{3} \mathrm{COO}^{-}\right), 1.75\left(\mathrm{~m}, 2 \mathrm{H}, \mathrm{CH}_{2}\right), 1.20$ $\left(\mathrm{m}, 2 \mathrm{H}, \mathrm{CH}_{2}\right), 0.84\left(\mathrm{t}, \mathrm{J} 14,3 \mathrm{H}, \mathrm{CH}_{3}\right)$.

\section{1-n-octyl-3-methylimidazolium}

acetate [OMIM][CH COO]: IR ( $\mathrm{KBr}) v / \mathrm{cm}^{-1} 3423,3081$, 2960, 1712, 1646, 1384, 1170, 518, 458; ${ }^{1} \mathrm{H}-\mathrm{NMR}$ (500 MHz, DMSO-d): $\delta$ (ppm): $7.36(\mathrm{~s}, 1 \mathrm{H}, \mathrm{CH})$, 7.02 (s, 1H, CH), 6.92 (s, 1H, CH), 4.08 (t, J 14,

Table 2 - Some properties of ILs at $25^{\circ} \mathrm{C}$

\begin{tabular}{l|c|c|c}
\hline \multicolumn{1}{c|}{ Property } & $\begin{array}{c}{[\mathrm{BMIM}]} \\
{\left[\mathrm{BF}_{4}\right]}\end{array}$ & $\begin{array}{c}\mathrm{BMIM}] \\
{\left[\mathrm{CH}_{3} \mathrm{COO}\right]}\end{array}$ & $\begin{array}{c}{[\mathrm{OMIM}]} \\
{\left[\mathrm{CH}_{3} \mathrm{COO}\right]}\end{array}$ \\
\hline Molar mass $\left(\mathrm{g} \mathrm{mol}^{-1}\right)$ & 226 & 198 & 255 \\
Density $\left(\mathrm{g} \mathrm{cm}^{-3}, 25^{\circ} \mathrm{C}\right)$ & 1.17 & 1.02 & 1.05 \\
Viscosity $\left(\mathrm{N} \mathrm{s} \mathrm{m}^{-2}, 25^{\circ} \mathrm{C}\right)$ & 0.1538 & 0.440 & 0.5451 \\
Melting point $\left({ }^{\circ} \mathrm{C}\right)$ & -71 & $<-20$ & -13 \\
\hline
\end{tabular}

$\left.2 \mathrm{H}, \mathrm{N}-\mathrm{CH}_{2}\right), 3.79\left(\mathrm{~s}, 3 \mathrm{H}, \mathrm{N}-\mathrm{CH}_{3}\right), 1.62(\mathrm{~m}, J$ 24, $10 \mathrm{H}), 1.81\left(\mathrm{~s}, 3 \mathrm{H}, \mathrm{CH}_{3} \mathrm{COO}^{-}\right), 0.75(\mathrm{t}, J 14,3 \mathrm{H}$, $\left.\mathrm{CH}_{3}\right)$.

Based on FT-IR and NMR, it was observed that synthesized ILs are [BMIM] $\left.\mathrm{BF}_{4}\right]$, [BMIM] [CH $\mathrm{CH}_{3} \mathrm{COO}$, and $[\mathrm{OMIM}]\left[\mathrm{CH}_{3} \mathrm{COO}\right]$. Some properties of the three ionic liquids are given in Table 2.

\section{Impregnation of ionic liquids on porous polymer membranes}

To evaluate the impregnation of ionic liquids on the pores of polymer membranes, their weight was determined gravimetrically before and after IL impregnation. The volume of immobilized ionic liquids was then determined and compared to the volume of pore of polymer membranes.

Table 3 -Determination of ionic liquids weight immobilized on polymer membranes

\begin{tabular}{|c|c|c|c|c|}
\hline $\begin{array}{l}\text { Mem- } \\
\text { brane }\end{array}$ & Ionic liquid & $\begin{array}{c}\text { Original } \\
\text { membrane } \\
\text { weight (g) }\end{array}$ & $\begin{array}{l}\text { Weight } \\
\text { of } \\
\text { SILMs } \\
(\mathrm{g})\end{array}$ & $\begin{array}{l}\text { IL weight } \\
\text { immobilized } \\
\text { on } \\
\text { membrane } \\
(\mathrm{g})\end{array}$ \\
\hline \multirow{3}{*}{ PVDF } & {$[\mathrm{BMIM}]\left[\mathrm{BF}_{4}\right]$} & \multirow{3}{*}{0.1353} & 0.3669 & 0.2316 \\
\hline & {$[\mathrm{BMIM}]\left[\mathrm{CH}_{3} \mathrm{COO}\right]$} & & 0.3577 & 0.2224 \\
\hline & {$[\mathrm{OMIM}]\left[\mathrm{CH}_{3} \mathrm{COO}\right]$} & & 0.3601 & 0.2256 \\
\hline \multirow{3}{*}{ PES } & {$[\mathrm{BMIM}]\left[\mathrm{BF}_{4}\right]$} & \multirow{3}{*}{0.069} & 0.2727 & 0.2183 \\
\hline & {$[\mathrm{BMIM}]\left[\mathrm{CH}_{3} \mathrm{COO}\right]$} & & 0.2768 & 0.2078 \\
\hline & {$[\mathrm{OMIM}]\left[\mathrm{CH}_{3} \mathrm{COO}\right]$} & & 0.2818 & 0.2128 \\
\hline \multirow{3}{*}{ CA } & {$[\mathrm{BMIM}]\left[\mathrm{BF}_{4}\right]$} & \multirow{3}{*}{0.079} & 0.2913 & 0.2123 \\
\hline & {$[\mathrm{BMIM}]\left[\mathrm{CH}_{3} \mathrm{COO}\right]$} & & 0.2801 & 0.2011 \\
\hline & {$[\mathrm{OMIM}]\left[\mathrm{CH}_{3} \mathrm{COO}\right]$} & & 0.2854 & 0.2064 \\
\hline
\end{tabular}

Table 4 -Pore volume of membrane and volume of ionic liquids immobilized on polymer membranes

\begin{tabular}{|c|c|c|c|}
\hline $\begin{array}{l}\text { Mem- } \\
\text { brane }\end{array}$ & Ionic liquid & $\begin{array}{c}\text { Pore volume } \\
\text { of membrane, } \\
\qquad V_{\text {por }}\left(\mathrm{m}^{3}\right)\end{array}$ & $\begin{array}{c}\text { Ionic liquids } \\
\text { volume } \\
\text { immobilized } \\
\text { on membrane, } \\
V_{\text {memb }}\left(\mathrm{m}^{3}\right) \\
\end{array}$ \\
\hline \multirow{3}{*}{ PVDF } & {$[\mathrm{BMIM}]\left[\mathrm{BF}_{4}\right]$} & \multirow{3}{*}{$0.195 \cdot 10^{-6}$} & $0.198 \cdot 10^{-6}$ \\
\hline & {$[\mathrm{BMIM}]\left[\mathrm{CH}_{3} \mathrm{COO}\right]$} & & $0.211 \cdot 10^{-6}$ \\
\hline & {$[\mathrm{OMIM}]\left[\mathrm{CH}_{3} \mathrm{COO}\right]$} & & $0.21510^{-6}$ \\
\hline \multirow{3}{*}{ PES } & {$[\mathrm{BMIM}]\left[\mathrm{BF}_{4}\right]$} & \multirow{3}{*}{$0.182 \cdot 10^{-6}$} & $0.186 \cdot 10^{-6}$ \\
\hline & {$[\mathrm{BMIM}]\left[\mathrm{CH}_{3} \mathrm{COO}\right]$} & & $0.202 \cdot 10^{-6}$ \\
\hline & {$[\mathrm{OMIM}]\left[\mathrm{CH}_{3} \mathrm{COO}\right]$} & & $0.203 \cdot 10^{-6}$ \\
\hline \multirow{3}{*}{$\mathrm{CA}$} & {$[\mathrm{BMIM}]\left[\mathrm{BF}_{4}\right]$} & \multirow{3}{*}{$0.182 \cdot 10^{-6}$} & $0.185 \cdot 10^{-6}$ \\
\hline & {$[\mathrm{BMIM}]\left[\mathrm{CH}_{3} \mathrm{COO}\right]$} & & $0.195 \cdot 10^{-6}$ \\
\hline & {$[\mathrm{OMIM}]\left[\mathrm{CH}_{3} \mathrm{COO}\right]$} & & $0.197 \cdot 10^{-6}$ \\
\hline
\end{tabular}




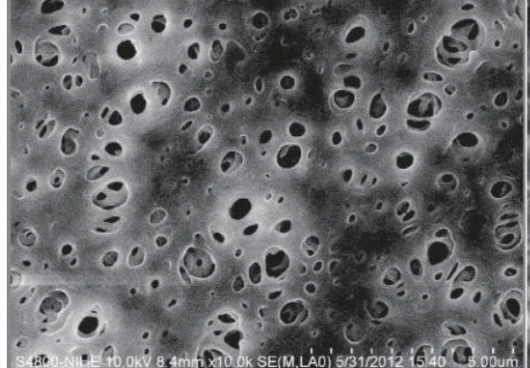

(a)

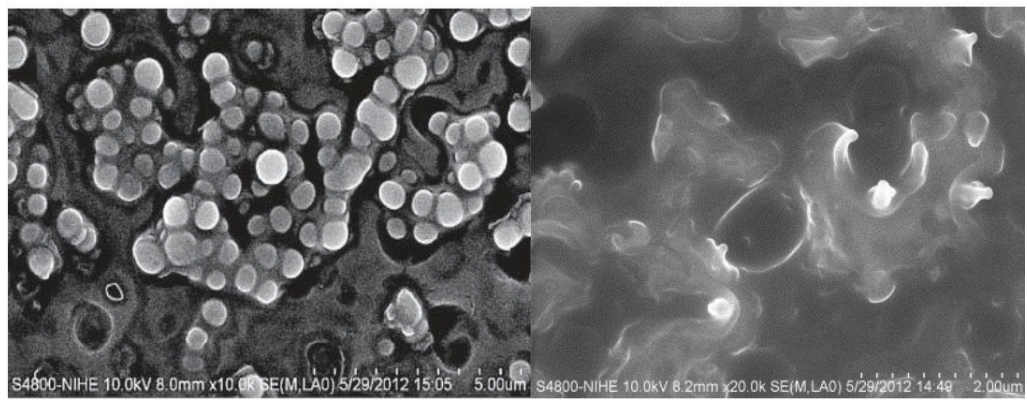

(c)

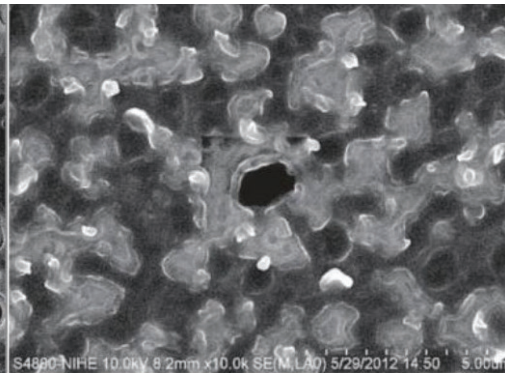

(b)

(d)
Fig. 3 - Surface of PES membranes before and after impregnation with different ILs (a: original, $b$ : after impregnation with [OMIM][CH$\left.{ }_{3} \mathrm{COO}\right], c$ : after im-

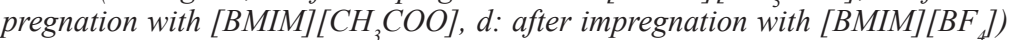

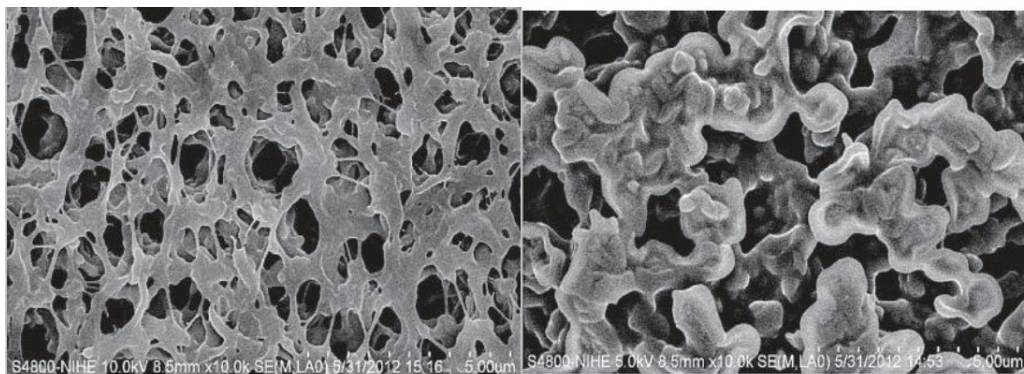

(a)

(b)

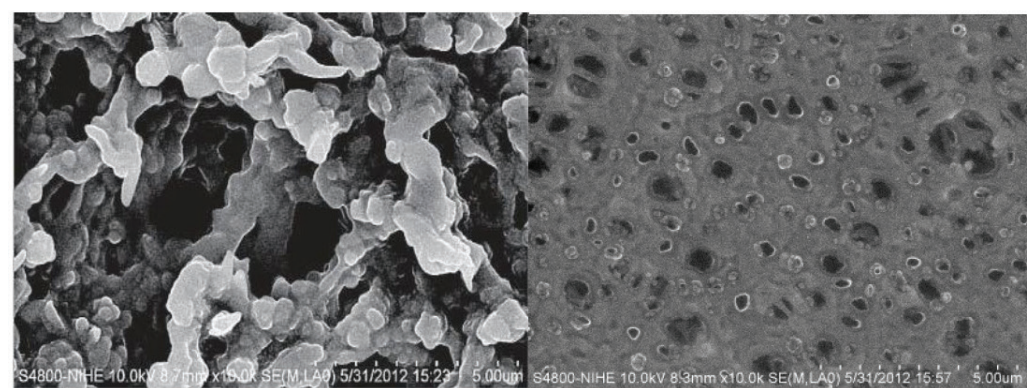

(c)

(d)

Fig. 4 - Surface of PVDF membranes before and after impregnation with dif-

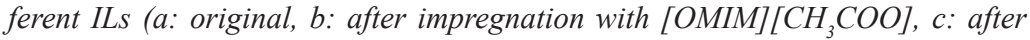
impregnation with [BMIM] $\left[\mathrm{CH}_{3} \mathrm{COO}\right]$, d: after impregnation with $\left.[B M I M]\left[\mathrm{BF}_{4}\right]\right)$

It can be seen from Tables 3 and 4 that the volumes of ionic liquids immobilized on polymer membrane are higher than the volume of membrane pores. This shows that all the pores of polymer membrane were filled with ionic liquids, while a part of ionic liquids covered the surface of membrane. In all the experiments, the volumes of immobilized tetrafluoroborate ionic liquid were lower than those of acetate ionic liquids. This can be explained by the difference in viscosity of the three ILs, the viscosity of [BMIM] $\left[\mathrm{BF}_{4}\right]\left(0.1538 \mathrm{~N} \mathrm{~s} \mathrm{~m}^{-2}\right)$ is lower than that of [BMIM] [CH $\mathrm{COO}](0.440$ $\left.\mathrm{N} \mathrm{s} \mathrm{m}{ }^{-2}\right)$ and of [OMIM] $\left[\mathrm{CH}_{3} \mathrm{COO}\right]$ $\left(0.5451 \mathrm{~N} \mathrm{~s} \mathrm{~m}^{-2}\right)$ at $25^{\circ} \mathrm{C}$.

\section{SEM results of original polymer membranes and SILMs}

Surface properties of membranes and SILMs were characterized by a Scanning Electron Microscope (SEM) S-4800, Hitachi High-Tech., Japan. The SEM images are shown in Figs. 3 - 5 . The appearance and mechanical stability of PVDF and PES membranes had not changed after impregnation with ionic liquids. The porous and uniform surfaces of membranes were covered in ionic liquids (Figs. $3-5$ ).

SEM images of cellulose acetate membranes before and after soaking in ionic liquids given in Fig. 5, show that the surface of membranes was destroyed. The mechanical stability of the membranes decreased dramatically and the membranes became much softer, which could also be observed by the naked eye. These results show that cellulose acetate membranes are not suitable for immobilizing ionic liquids because some ILs can dissolve the biomass-based polymers. This is consistent with the results of experimental work carried out by Hou et al. ${ }^{38}$ Some ionic liquids can dissolve lignin and cellulose, and many researchers focus on using them as solvents for pretreating biomass to produce bioethanol.

The instability of cellulose acetate membrane was clearly observed during investigation of the influence of pressure difference between feed and permeate compartments on the stability of SILPs (see the next section).

\section{Appropriate pressure difference between feed and permeate compartments}

Different ILs within nine SILMs made from three distinct polymeric 


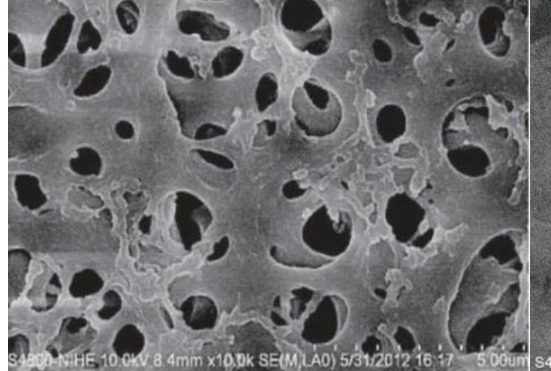

(a)

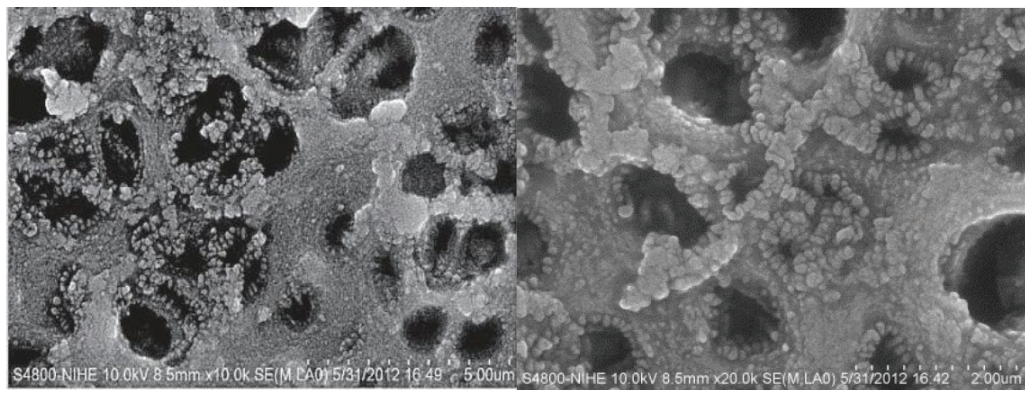

(c) (d)
Fig. 5 - Surface of cellulose acetate membrane before and after impregnation with different ILs (a: original, b: after impregnation with [OMIM] [CH $\left.\mathrm{CH}_{3} \mathrm{COO}\right]$, c: after impregnation with $[\mathrm{BMIM}]\left[\mathrm{CH}_{3} \mathrm{COO}\right]$, d: after impregnation with $[\mathrm{BMIM}]\left[\mathrm{BF}_{4}\right]$ )

membranes and three ionic liquids were tested in order to select the best membrane support and the best range of pressure difference between the two compartments of the system.

The stability of investigated SILPs as a function of initial transmembrane pressure is shown in Table 5. When the initial transmembrane pressure increased, the stability of SILMs deceased; the membranes can even be broken when the initial

Table 5-Differential pressure between feed compartment and permeate compartment

\begin{tabular}{|c|c|c|c|c|c|c|c|}
\hline $\begin{array}{c}\text { Pressure (bar) } \\
\text { SILMs }\end{array}$ & 0.4 & 0.7 & 1 & 1.3 & 1.5 & 1.7 & 1.9 \\
\hline$[\mathrm{BMIM}]\left[\mathrm{BF}_{4}\right] / \mathrm{PES}$ & $\checkmark$ & $\checkmark$ & $\checkmark$ & $\checkmark$ & $x$ & & \\
\hline$[\mathrm{BMIM}]\left[\mathrm{CH}_{3} \mathrm{COO}\right] / \mathrm{PES}$ & $\checkmark$ & $\checkmark$ & $\checkmark$ & $\checkmark$ & $x$ & & \\
\hline$[\mathrm{OMIM}]\left[\mathrm{CH}_{3} \mathrm{COO}\right] / \mathrm{PES}$ & $\checkmark$ & $\checkmark$ & $\checkmark$ & $\checkmark$ & $x$ & & \\
\hline$[\mathrm{BMIM}]\left[\mathrm{BF}_{4}\right] / \mathrm{PVDF}$ & $\checkmark$ & $\checkmark$ & $\checkmark$ & $\checkmark$ & $\checkmark$ & $\checkmark$ & $x$ \\
\hline$[\mathrm{BMIM}]\left[\mathrm{CH}_{3} \mathrm{COO}\right] / \mathrm{PVDF}$ & $\checkmark$ & $\checkmark$ & $\checkmark$ & $\checkmark$ & $\checkmark$ & $\checkmark$ & $x$ \\
\hline$[\mathrm{OMIM}]\left[\mathrm{CH}_{3} \mathrm{COO}\right] / \mathrm{PVDF}$ & $\checkmark$ & $\checkmark$ & $\checkmark$ & $\checkmark$ & $\checkmark$ & $\checkmark$ & $x$ \\
\hline$[\mathrm{BMIM}]\left[\mathrm{BF}_{4}\right] / \mathrm{CA}$ & $x$ & & & & & & \\
\hline$[\mathrm{BMIM}]\left[\mathrm{CH}_{3} \mathrm{COO}\right] / \mathrm{CA}$ & $\checkmark$ & $x$ & & & & & \\
\hline$[\mathrm{OMIM}]\left[\mathrm{CH}_{3} \mathrm{COO}\right] / \mathrm{CA}$ & $\checkmark$ & $x$ & & & & & \\
\hline
\end{tabular}

transmembrane pressure is high enough. The PVDF based SILMs have the highest stability, while the cellulose acetate membranes showed the lowest stabilities. These results and the obtained SEM results demonstrated that cellulose acetate membranes are not stable in contact with [BMIM] $\left[\mathrm{BF}_{4}\right]$, [BMIM] $\left[\mathrm{CH}_{3} \mathrm{COO}\right]$, and $[\mathrm{OMIM}]\left[\mathrm{CH}_{3} \mathrm{COO}\right]$ ionic liquids. SILMs from PES and PVDF membranes with high stability were used for experiments of measuring permeability of gases and membrane selectivity. The pressure difference in the range of $0.7-1.3$ at was selected for gas permeability and selectivity measurements to ensure the stability of SILMs.

\section{Single gas permeation results}

The effect of ILs structure (different alkyl chain length and distinct anions) and of polymer membranes on the membrane permeability and selectivity was studied for the pure gases $\mathrm{CH}_{4}$ and $\mathrm{CO}_{2}$.

All the permeability, selectivity and separation yield values were calculated according to Eqs. 5 7. Table 6 shows permeability of pure $\mathrm{CO}_{2}$ and $\mathrm{CH}_{4}$ gases through the supported ionic liquids membrane. $\mathrm{CO}_{2}$ permeability was higher than $\mathrm{CH}_{4}$ permeability for all the SILMs. There is a small difference in molecular size between these two gases $\left(3.69 \cdot 10^{-10} \mathrm{~m}\right.$ for $\mathrm{CO}_{2}$ and $\left.3.76 \cdot 10^{-10} \mathrm{~m}_{\text {for }} \mathrm{CH}_{4}\right)$, therefore, the difference in permeability is due to the higher polarity of $\mathrm{CO}_{2}$ compared to that of $\mathrm{CH}_{4}$.

\section{Influence of the IL cation}

The $\mathrm{CO}_{2}$ and $\mathrm{CH}_{4}$ permeability of the SILMs prepared with two hydrophilic supports and two different ILs was measured for the different alkyl chain length of the 1-alkyl side chain of cations. The influence of the alkyl chain length of the 1-alkyl side chain of cations for the anions $\left[\mathrm{CH}_{3} \mathrm{COO}\right]^{-}$

Table 6 - Single gas $\mathrm{CO}_{2}$ and $\mathrm{CH}_{4}$ permeability with SILMs

\begin{tabular}{c|l|c|c}
\hline \multirow{2}{*}{ Entries } & \multirow{2}{*}{$\begin{array}{c}\text { Supported ionic liquid } \\
\text { membranes }\end{array}$} & \multicolumn{2}{c}{$\begin{array}{c}\text { Permeability of a } \\
\text { pure gas } \cdot 10^{-11}\left(\mathrm{~m}^{2} \mathrm{~s}^{-1}\right)\end{array}$} \\
\cline { 3 - 4 } & & $\mathrm{CO}_{2}$ & $\mathrm{CH}_{4}$ \\
\hline 1 & {$[\mathrm{BMIM}]\left[\mathrm{BF}_{4}\right] / \mathrm{PES}$} & $41.90 \pm 0.51$ & $1.87 \pm 0.12$ \\
2 & {$[\mathrm{BMIM}]\left[\mathrm{CH}_{3} \mathrm{COO}\right] / \mathrm{PES}$} & $32.90 \pm 0.50$ & $2.13 \pm 0.15$ \\
3 & {$[\mathrm{OMIM}]\left[\mathrm{CH}_{3} \mathrm{COO}\right] / \mathrm{PES}$} & $59.50 \pm 0.55$ & $3.13 \pm 0.14$ \\
4 & {$[\mathrm{BMIM}]\left[\mathrm{BF}_{4}\right] / \mathrm{PVDF}$} & $46.60 \pm 0.45$ & $1.95 \pm 0.10$ \\
5 & {$[\mathrm{BMIM}]\left[\mathrm{CH}_{3} \mathrm{COO}\right] / \mathrm{PVDF}$} & $38.30 \pm 0.35$ & $2.17 \pm 0.18$ \\
6 & {$[\mathrm{OMIM}]\left[\mathrm{CH}_{3} \mathrm{COO}\right] / \mathrm{PVDF}$} & $65.98 \pm 0.65$ & $3.22 \pm 0.21$ \\
\hline
\end{tabular}


on the permeability of $\mathrm{CO}_{2}$ and $\mathrm{CH}_{4}$ gases of PES and PVDF based SILPs, is presented in Table 6. For easy analysis, the permeability ratios for the pair $\mathrm{C}_{8} \mathrm{MIM}^{+} / \mathrm{C}_{4} \mathrm{MIM}^{+}$with the respective membranes PVDF and PES, are given in Table $7 .{ }^{30}$ From the data in Table 7, $\mathrm{CO}_{2}$ permeability increases approximately 2 times and $\mathrm{CH}_{4}$ permeability increases approximately 1.5 times with an increase in the carbon numbers of the 1-alkyl side chain of cation for both PVDF and PES membranes. In addition, the diffusion of gases through respective SILPs should decrease due to higher viscosity of [OMIM] $\left[\mathrm{CH}_{3} \mathrm{COO}\right]$ compared with [BMIM] $\left[\mathrm{CH}_{3} \mathrm{COO}\right]$. Therefore, the resulting estimated permeability must increase by a higher factor. These results show that solubility of gases in ionic liquids significantly affects the transport of gases through ILs with different alkyl chain length of the 1-alkyl side chain of cations. The structure of membrane only slightly affects the permeability of gases, and the permeability of gases through the PVDF membrane is higher than through PES membrane.

\section{Influence of the IL anion and membrane structure}

The influence of structure of anions on the permeability of SILPs was also investigated. The viscosity has a significant influence on the permeability of $\mathrm{CH}_{4}$ through SILMs. Permeability of gases using SILPs based on [BMIM] and anion $\left[\mathrm{CH}_{3} \mathrm{COO}\right]^{-}$is lower than using SILPs that contain the same cation and $\left[\mathrm{BF}_{4}\right]^{-}$anion, which have lower viscosity. The permeability increased from [BMIM] $\left[\mathrm{CH}_{3} \mathrm{COO}\right]$ to $\left.[\mathrm{OMIM}]\left[\mathrm{CH}_{3} \mathrm{COO}\right]\right)$ for both PVDF and PES membranes even though the viscosity increased correspondingly. However, the permeability of low-interacting gas $\left(\mathrm{CH}_{4}\right)$ changed only slightly.

In order to evaluate the feasibility of $\mathrm{CO}_{2} / \mathrm{CH}_{4}$ separation using SILPs, the $\mathrm{CO}_{2} / \mathrm{CH}_{4}$ ideal selectivities for the membranes tested were calculated. The higher permeability of $\mathrm{CO}_{2}$ compared to $\mathrm{CH}_{4}$ points to the possibility of separation of $\mathrm{CO}_{2}$ from its mixture with $\mathrm{CH}_{4}$.

Ideal selectivity and separation yield depend on the type of ionic liquids and carriers (polymer membranes). In this study, the SILP formed from ionic liquid $[\mathrm{BMIM}]\left[\mathrm{BF}_{4}\right]$ and PVDF membrane showed the highest selectivity and yield, $23.9 \%$ and $96 \%$, respectively. The other SILPs also gave high selectivity with ideal yield over $94 \%$.

\section{Gas mixture permeation results}

Gas mixture permeation of SILPs was calculated based on the change in composition of gas mixtures in feed and permeate compartments, which was measured using GC-TCD online analysis. The SILPs studied were made from three ILs $[\mathrm{BMIM}]\left[\mathrm{BF}_{4}\right]$,
$[\mathrm{BMIM}]\left[\mathrm{CH}_{3} \mathrm{COO}\right]$, and $[\mathrm{OMIM}]\left[\mathrm{CH}_{3} \mathrm{COO}\right]$, and two kinds of membrane materials - PVDF and PES. The gas mixture $\left(\mathrm{CO}_{2}\right.$ and $\mathrm{CH}_{4}$ with a 50:50 volume ratio) was injected into feed and permeate compartments with the suitable initial transmembrane pressures which were chosen as already described above. The selectivity and yield were calculated from obtained gas compositions (Table 9).

Similarly to the ideal case, SILMs made of $[\mathrm{BMIM}]\left[\mathrm{BF}_{4}\right]$ gave the higher selectivities when compared to those of other ILs. The selectivities of [BMIM] $\left[\mathrm{BF}_{4}\right]$-based SILMs reached 21.1 for PES membrane and 22.8 for PVDF membrane, and the separation yields reached 95.7 and 95.9 , respectively. [OMIM] $\left[\mathrm{CH}_{3} \mathrm{COO}\right]$-based SILPs also lead to rather high selectivities and yields (selectivities of 17.3 and 19.5; separation yields of 94.5 and 95.1, respectively). However, the low cost and stability of [OMIM] $\left[\mathrm{CH}_{3} \mathrm{COO}\right]$ ionic liquid towards moisture makes its SILPs more preferable.

Table 7 -Permeability ratios for the pair $C_{8} M I M^{+} / C_{4} M I M$ with the respective membranes $P V D F$ and PES

\begin{tabular}{l|c|c|c}
\hline \multirow{2}{*}{ Permeability ratio } & \multirow{2}{*}{ Membrane } & \multicolumn{2}{|c}{$\mathrm{Gas}$} \\
\cline { 3 - 4 } & & $\mathrm{CO}_{2}$ & $\mathrm{CH}_{4}$ \\
\hline $\mathrm{C}_{8} \mathrm{MIM}^{+} / \mathrm{C}_{4} \mathrm{MIM}^{+}$ & $\mathrm{PVDF}$ & 1.89 & 1.48 \\
$\mathrm{C}_{8} \mathrm{MIM}^{+} / \mathrm{C}_{4} \mathrm{MIM}^{+}$ & $\mathrm{PES}$ & 2.02 & 1.47 \\
\hline
\end{tabular}

Table 8 - Ideal $\mathrm{CO}_{2} / \mathrm{CH}_{4}$ selectivity and performance of SILMS

\begin{tabular}{l|c|c}
\hline $\begin{array}{c}\text { Supported ionic liquid } \\
\text { membranes }\end{array}$ & $\begin{array}{c}\text { Ideal selectivity } \\
\text { of } \mathrm{CO}_{2} / \mathrm{CH}_{4}\end{array}$ & $\begin{array}{c}\text { Ideal separation } \\
\text { yield (\%) }\end{array}$ \\
\hline$[\mathrm{BMIM}]\left[\mathrm{BF}_{4}\right] / \mathrm{PES}$ & $22.41 \pm 0.26$ & $95.73 \pm 0.03$ \\
{$[\mathrm{BMIM}]\left[\mathrm{CH}_{3} \mathrm{COO}\right] / \mathrm{PES}$} & $15.45 \pm 0.23$ & $93.92 \pm 0.05$ \\
{$[\mathrm{OMIM}]\left[\mathrm{CH}_{3} \mathrm{COO}\right] / \mathrm{PES}$} & $19.01 \pm 0.21$ & $95.00 \pm 0.04$ \\
{$[\mathrm{BMIM}]\left[\mathrm{BF}_{4}\right] / \mathrm{PVDF}$} & $23.90 \pm 0.25$ & $95.98 \pm 0.03$ \\
{$[\mathrm{BMIM}]\left[\mathrm{CH}_{3} \mathrm{COO}\right] / \mathrm{PVDF}$} & $17.65 \pm 0.31$ & $94.64 \pm 0.06$ \\
{$[\mathrm{OMIM}]\left[\mathrm{CH}_{3} \mathrm{COO}\right] / \mathrm{PVDF}$} & $20.49 \pm 0.35$ & $95.35 \pm 0.08$ \\
\hline
\end{tabular}

Table $9-\mathrm{CO}_{2} / \mathrm{CH}_{4}$ selectivity and performance of SILMs in case of gas mixture

\begin{tabular}{lcc}
\hline $\begin{array}{c}\text { Supported ionic liquid } \\
\text { membranes }\end{array}$ & $\begin{array}{c}\text { Selectivity of } \\
\mathrm{CO}_{2} / \mathrm{CH}_{4}\end{array}$ & $\begin{array}{c}\text { Separation yield } \\
(\%)\end{array}$ \\
\hline$[\mathrm{BMIM}]\left[\mathrm{BF}_{4}\right] / \mathrm{PES}$ & $21.11 \pm 0.32$ & $95.48 \pm 0.06$ \\
{$[\mathrm{BMIM}]\left[\mathrm{CH}_{3} \mathrm{COO}\right] / \mathrm{PES}$} & $13.91 \pm 0.23$ & $93.29 \pm 0.04$ \\
{$[\mathrm{OMIM}]\left[\mathrm{CH}_{3} \mathrm{COO}\right] / \mathrm{PES}$} & $17.31 \pm 0.32$ & $94.54 \pm 0.03$ \\
{$[\mathrm{BMIM}]\left[\mathrm{BF}_{4}\right] / \mathrm{PVDF}$} & $22.82 \pm 0.22$ & $95.80 \pm 0.02$ \\
{$[\mathrm{BMIM}]\left[\mathrm{CH}_{3} \mathrm{COO}\right] / \mathrm{PVDF}$} & $15.84 \pm 0.24$ & $94.06 \pm 0.03$ \\
{$[\mathrm{OMIM}]\left[\mathrm{CH}_{3} \mathrm{COO}\right] / \mathrm{PVDF}$} & $19.50 \pm 0.31$ & $95.12 \pm 0.05$ \\
\hline
\end{tabular}


The selectivities measured with gas mixtures are lower than ideal selectivities as calculated by equation (5) by 6 to $8 \%$. This is explained as follows: The permeability of each gas is proportional to its concentration in the mixture. When the permeation takes place, for a while, the concentration of $\mathrm{CO}_{4}$ decreases whereas that of $\mathrm{CH}_{4}$ increases because of the higher permeability of $\mathrm{CO}_{2}$ than that of $\mathrm{CH}_{4}$. This leads to the decreased selectivity as calculated by eq. (5) with respect to the value calculated by eq. (5). However, the yields only decreased by $0.2-0.3 \%$ in the gas mixture case.

\section{Conclusions}

Ionic liquids [BMIM][ $\left.\mathrm{BF}_{4}\right],[\mathrm{BMIM}]\left[\mathrm{CH}_{3} \mathrm{COO}\right]$, and $[\mathrm{OMIM}]\left[\mathrm{CH}_{3} \mathrm{COO}\right]$ were successfully synthesized, characterized, and impregnated on PES, PVDF, and CA membranes by direct impregnation method. The calculation results of the amount of ionic liquids immobilized on membranes as well as SEM results showed that ionic liquids filled the pores of the polymer membranes, while a small portion was on surface of the membranes. The amount of ionic liquid [OMIM] $\left[\mathrm{CH}_{3} \mathrm{COO}\right]$ immobilized on the membranes was higher than that on [BMIM] $\left[\mathrm{CH}_{3} \mathrm{COO}\right]$ and $[\mathrm{BMIM}]\left[\mathrm{BF}_{4}\right]$ because of its higher viscosity. Among membranes used, cellulose acetate swelled after impregnation with ionic liquids, therefore, it is not suitable for carrying investigated ionic liquids. This conclusion is also con- sistent with SEM measurements. The PVDF-based SILPs showed the highest stability and the suitable pressure difference between feed compartment and permeate compartment determined was from 0.7 to 1.5 bar.

The supported ionic liquid membranes in this study showed the selective permeability of $\mathrm{CO}_{2}$ and high ability of separation of $\mathrm{CO}_{2}$ from its mixture with $\mathrm{CH}_{4}$. The $\mathrm{CO}_{2} / \mathrm{CH}_{4}$ selectivities and corresponding separation yield of SILPs increased with increasing the carbon numbers of the 1-alkyl side chain of cation in IL (from [BMIM to [OMIM]), and with the change in the counterion from $\left[\mathrm{CH}_{3} \mathrm{COO}\right]$ to $\left[\mathrm{BF}_{4}\right]$. The SILPs prepared from $\mathrm{PVDF}$ gave higher $\mathrm{CO}_{2} / \mathrm{CH}_{4}$ selectivities and separation yields when compared to those from PES. The SILPs prepared from [OMIM] $\left[\mathrm{CH}_{3} \mathrm{COO}\right]$ are preferable because of their stability, absence of halogens, and lower price.

\section{SUPPLEMENTARY INFORMATION}

The information of ILs spectra (FT-IR, NMR) are presented in "Supplementary Information" Section.

\section{ACKNOWLEDGEMENTS}

Financial support from the Ministry of Science and Technology, Vietnam, is gratefully acknowledged.

\section{Supplementary information}

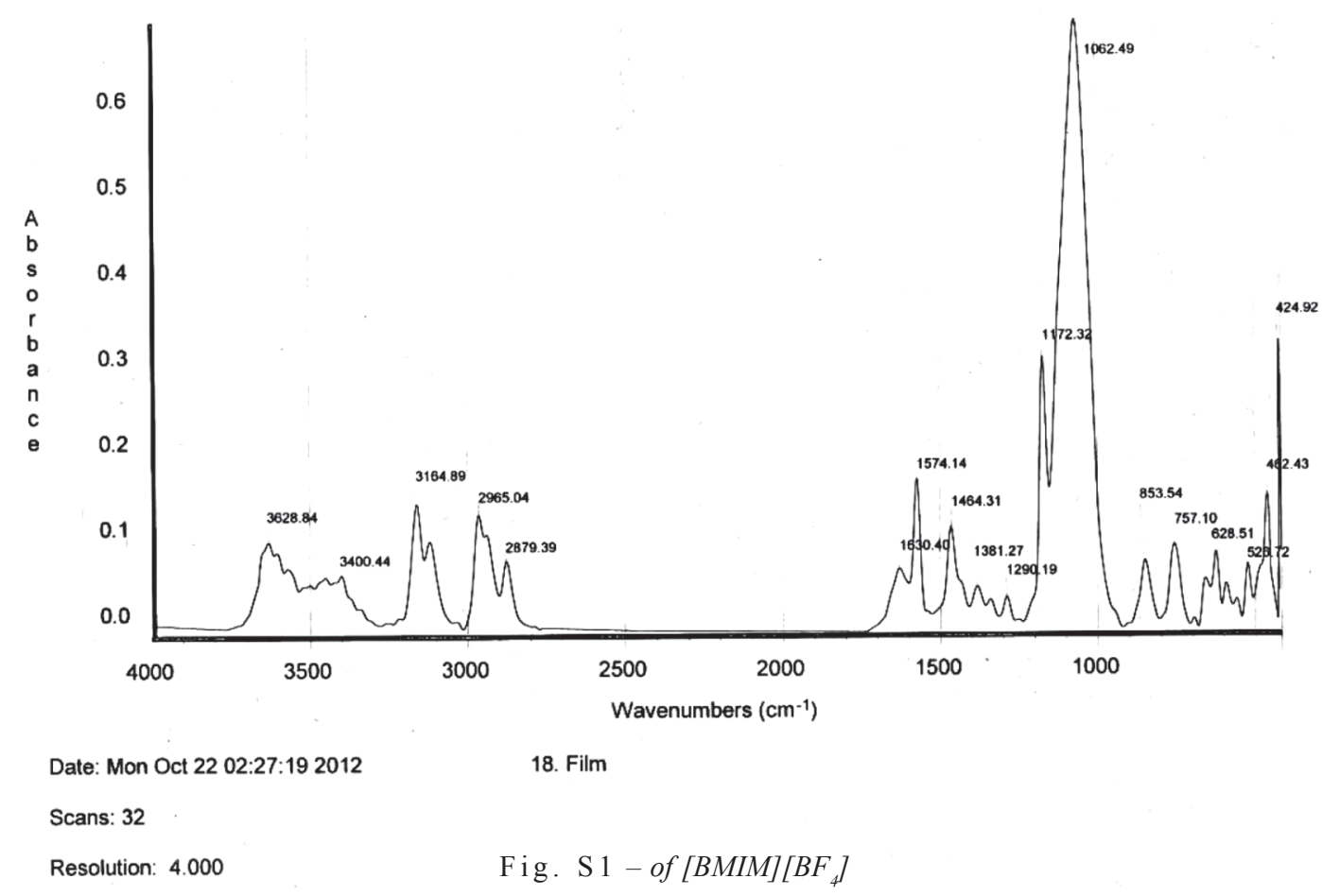




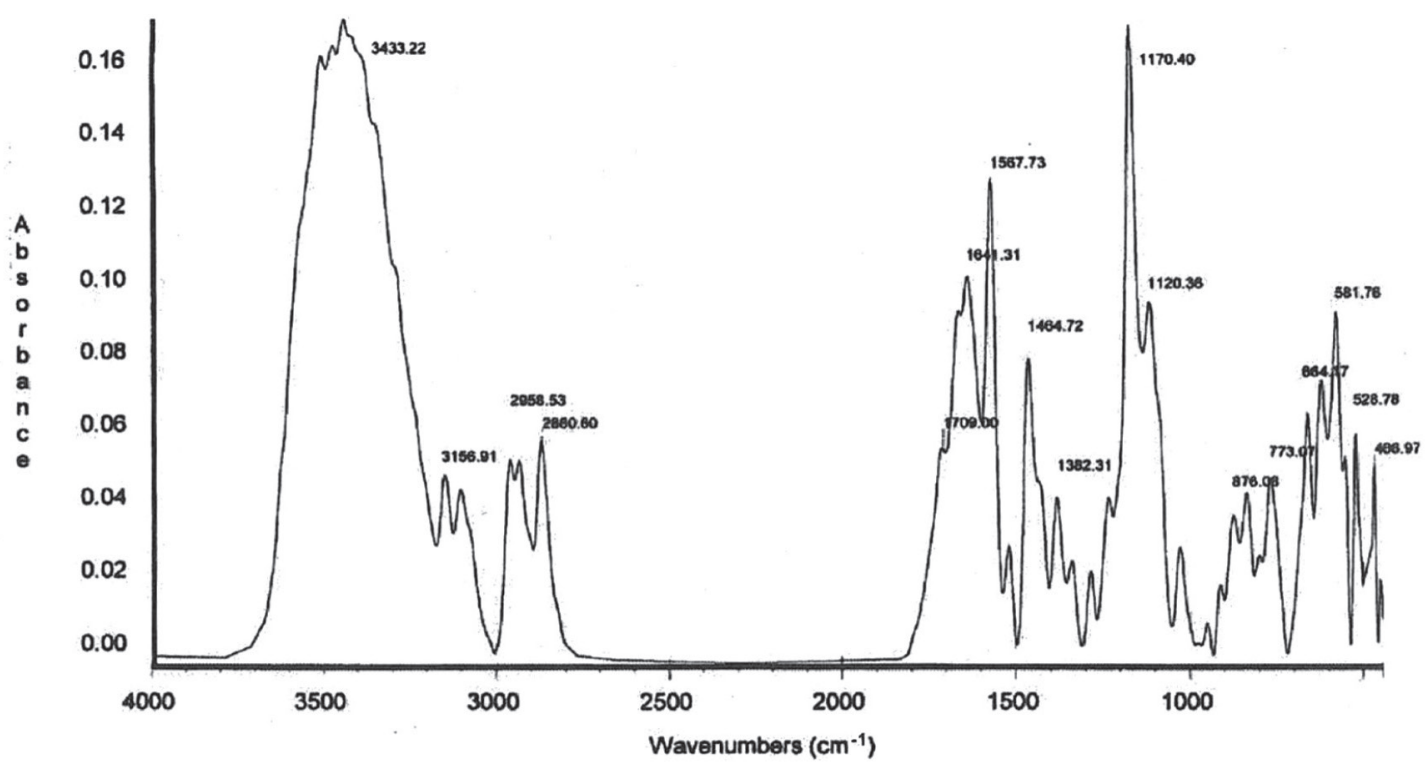

Date: Tue May 29 23:11:09 2012

3. Film

Scans: 32

Resolution: 4.000

Fig. S2 - FT-IR spectrum of [BMIM] $\left[\mathrm{CH}_{3} \mathrm{COO}\right]$

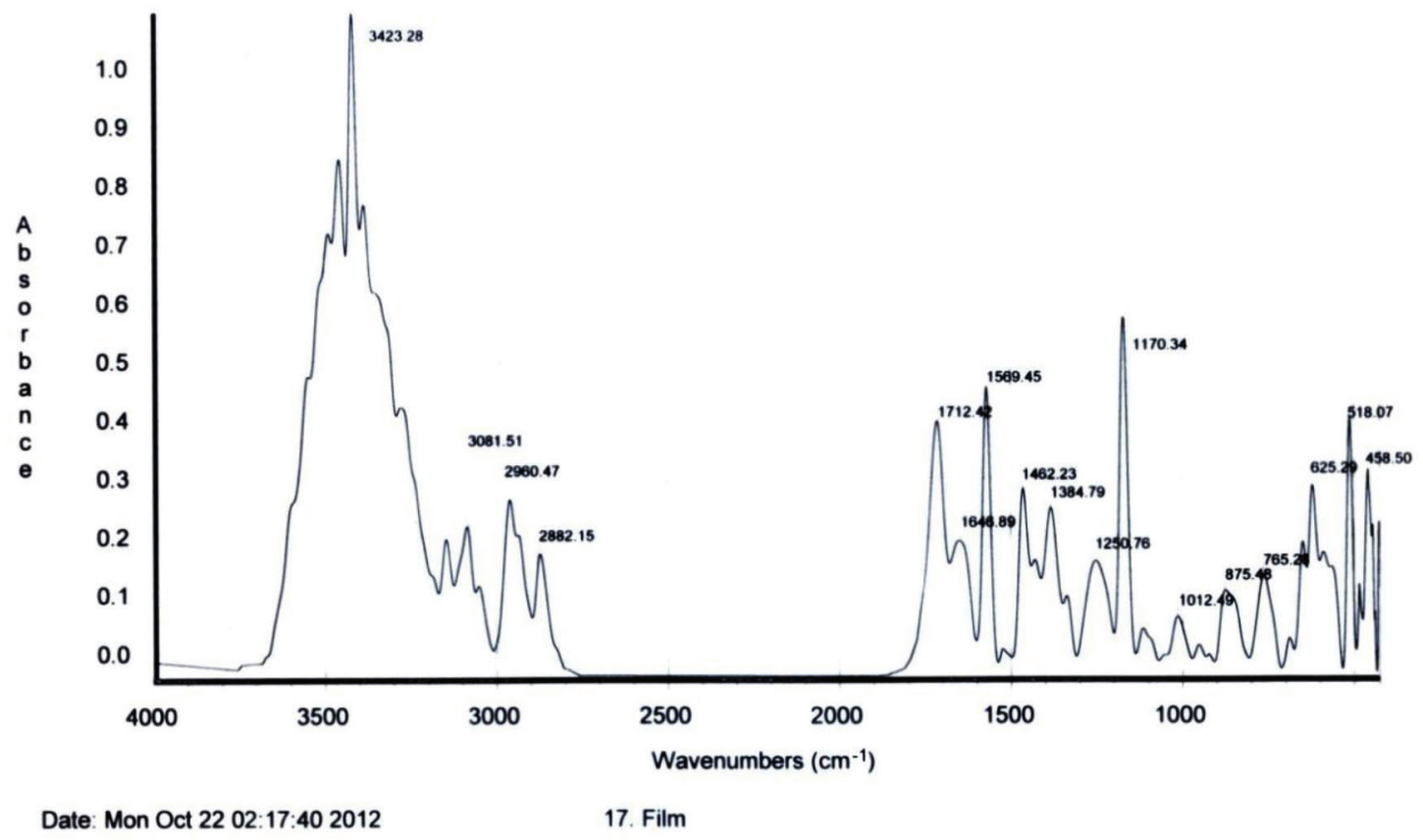

Scans: 32 


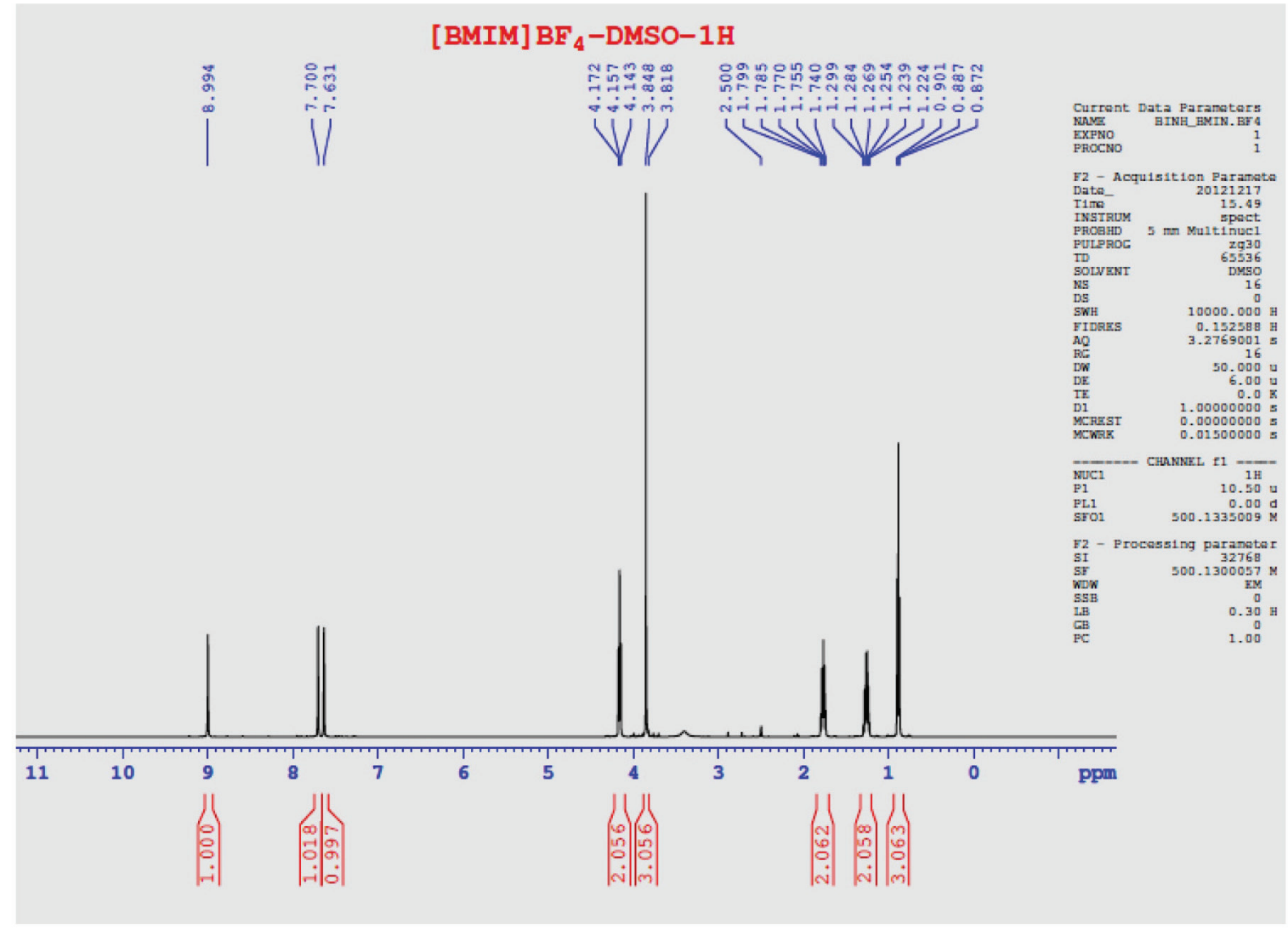

Fig. S 4 - FT-IR spectrum of $[B M I M]\left[B F_{4}\right]$

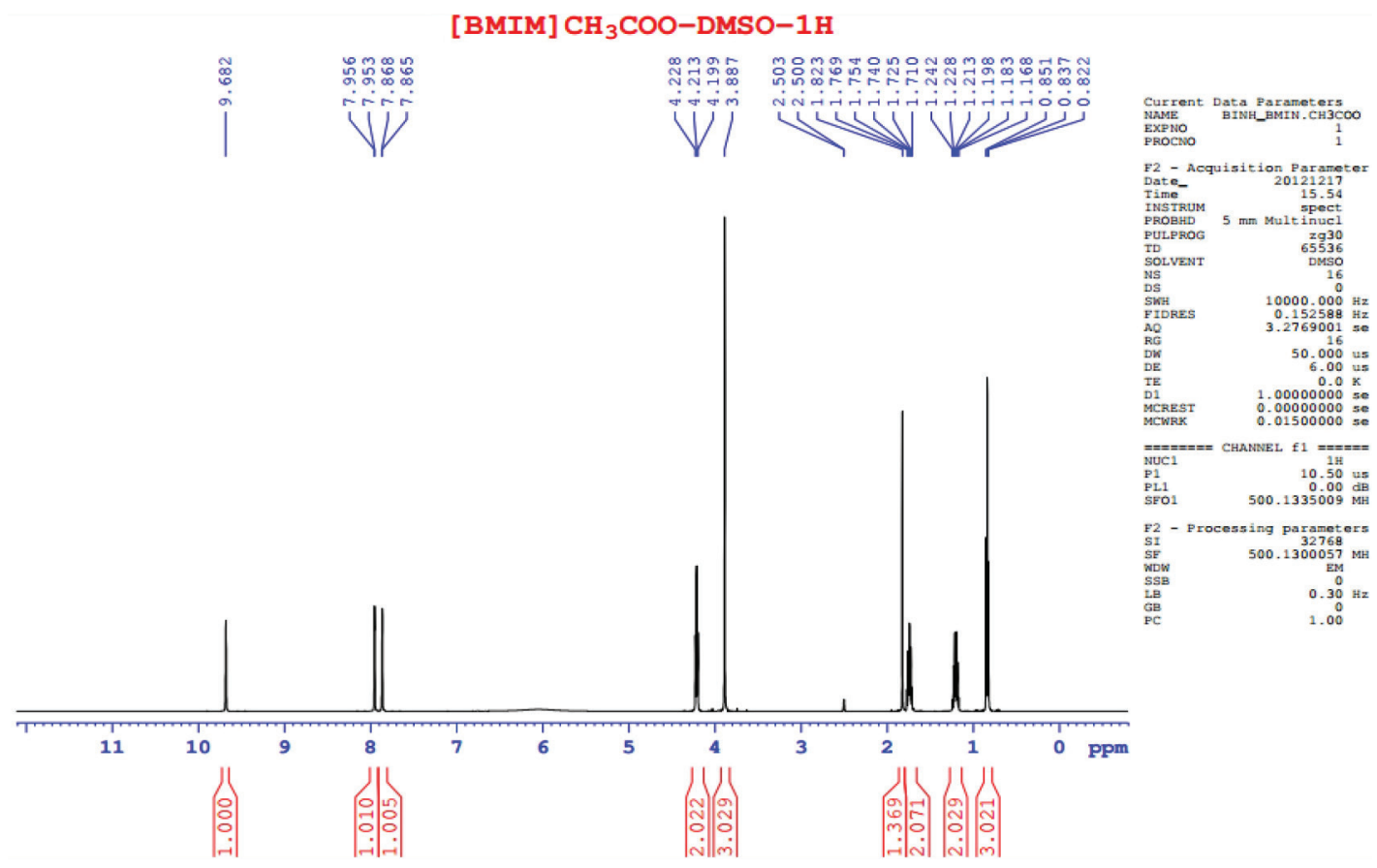

Fig. S $5-{ }^{1} \mathrm{H}$ NMR spectra of [BMIM][CH $\left.\mathrm{CH}_{3} \mathrm{COO}\right]$ 

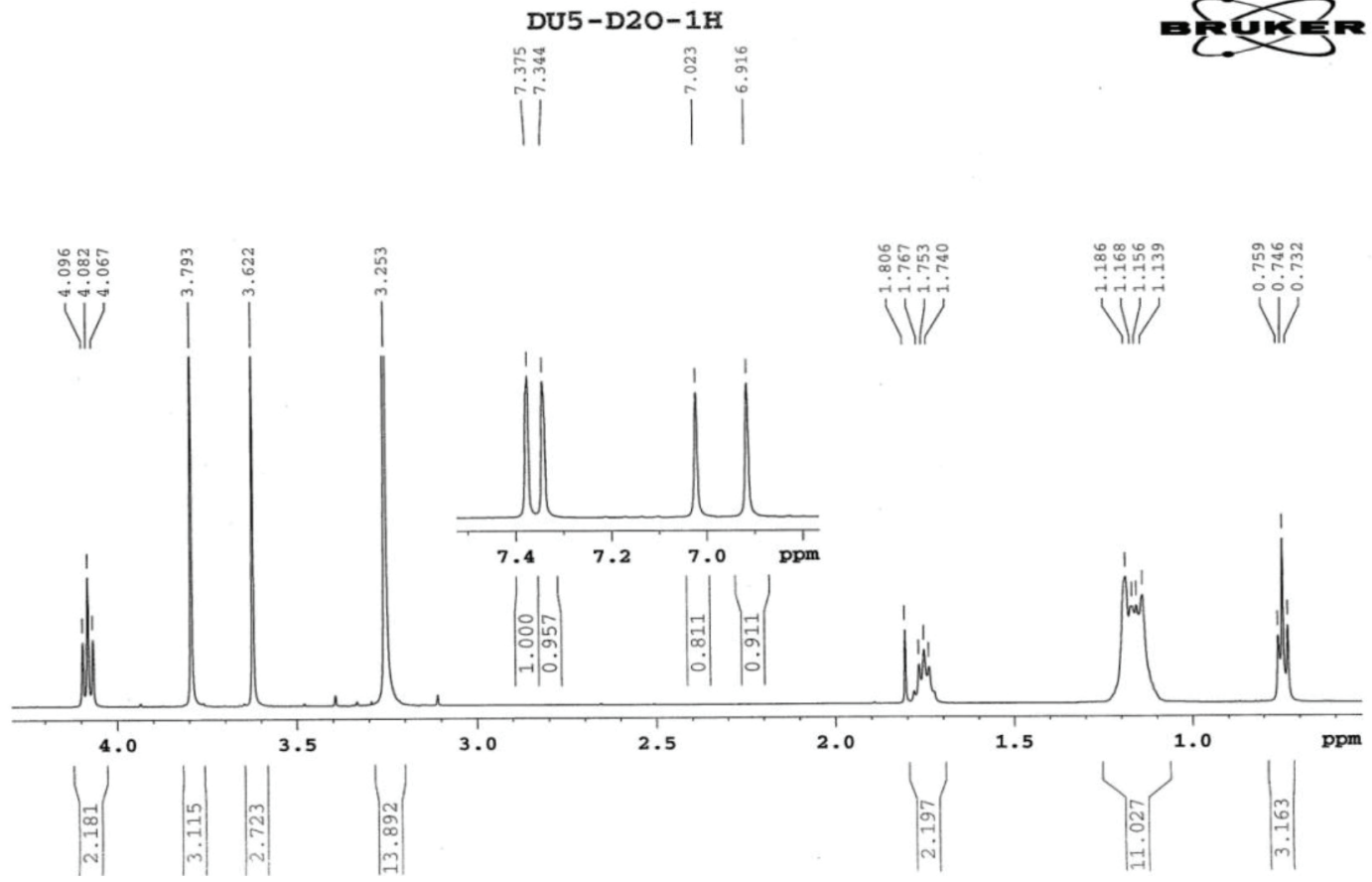

Fig. S $6-{ }^{1} \mathrm{H}$ NMR spectra of [OMIM] $\left[\mathrm{CH}_{3} \mathrm{COO}\right]$

\section{Abbreviations}

CA - cellulose acetate

$[\mathrm{BMIM}]\left[\mathrm{BF}_{4}\right] \quad$ - 1-n-butyl-3-methylimidazolium tetrafluoroborate

[BMIM] $\left[\mathrm{CH}_{3} \mathrm{COO}\right]$ - 1-n-butyl-3-methylimidazolium acetate

FT-IR - Fourier transform infrared spectroscopy

IL $\quad-$ ionic liquid

ILs $\quad-$ ionic liquids

NMR - nuclear magnetic resonance

[OMIM] $\left[\mathrm{CH}_{3} \mathrm{COO}\right]$ - 1-n-octyl-3-methylimidazolium acetate

PES - polyethersulfone

PVDF - polyvinylidene fluoride

SILP - supported ionic liquid membrane

SILMs - supported ionic liquid membranes

SEM - scanning electronic microscopy

\section{References}

1. Shimekit, B., Mukhtar, H., Chapter 9: Natural Gas Purification Technologies - Major Advances for $\mathrm{CO}_{2}$ Separation and Future Directions, Advances in Natural Gas Technology, Chapter 9, $1^{\text {st }}$ ed.; Intech, 2012.

2. Brunetti, A., Scura, F., Barbieri, G., Drioli, E., Membrane technologies for $\mathrm{CO}_{2}$ separation, J. Membr. Sci. 35 (2010) 115 .

doi: https://doi.org/10.1016/j.memsci.2009.11.040

3. Figueroa, J. D., Fout, T., Plasynski, S., McIlvried, H., Srivastava, R. D., Advances in $\mathrm{CO}_{2}$ capture technology-The U.S. Department of Energy's Carbon Sequestration Program, Int. J. Greenh. Gas Cont. 2 (2008) 9. doi: https://doi.org/10.1016/S1750-5836(07)00094-1
4. Schell, W. J., Houston, C. D., Hopper W. L., Membranes can efficiently separate carbon dioxide from mixtures, Oil Gas J. 81 (1983) 52.

5. Wahby, A., Silvestre-Albero, J., Sepúlveda-Escribano, A., Rodriguez-Reinoso, F., $\mathrm{CO}_{2}$ adsorption on carbon molecular sieves, Microporous Mesoporous Mater. 164 (2012) 280. doi: https://doi.org/10.1016/j.micromeso.2012.06.034

6. Ritter, A. J., Ebner, D. A., State-of-the-art adsorption and membrane separation processes for hydrogen production in the chemical and petrochemical industries, Sep. Sci. Technol. 42 (2007) 1123. doi: https://doi.org/10.1080/01496390701242194

7. Teramoto, M., Takeuchi, N., Maki, T., Matsuyama, H., Gas separation by liquid membrane accompanied by permeation of membrane liquid through membrane physical transport, Sep. Sci. Technol. 24 (2001) 101. doi: https://doi.org/10.1016/S1383-5866(00)00216-1

8. Ito, A., Duan, S., Ikenori, Y., Ohkawa, A., Permeation of wet $\mathrm{CO}_{2} / \mathrm{CH}_{4}$, mixed gas through a liquid membrane supported on surface of a hydrophobic microporous membrane, Sep. Sci. Technol. 24 (2001) 235. doi: https://doi.org/10.1016/S1383-5866(01)00124-1

9. Noble, R. D., Way, J. D., Description of Facilitated Transport and Environmental Applications in Crespo, J. G. and Böddeker, C. W. (Eds.), Membrane Processes in Separation and Purification, Kluwer Academic Publishers, Dordrecht, 1994, pp. 317-342. doi: https://doi.org/10.1007/978-94-015-8340-4_15

10. Welton, T., Room-temperature ionic liquids, solvents for synthesis and catalysis, Chem. Rev. 99 (1999) 2071. doi: https://doi.org/10.1021/cr980032t

11. Wu, W., Han, B., Gao, H., Liu, Z., Jiang, T., Huang, J., Sulfurization of flue gas: $\mathrm{SO}_{2}$ absorption by an ionic liquid, Angew. Chem. Int. Ed. 43 (2004) 2415. doi: https://doi.org/10.1002/anie.200353437

12. Keskin, S., Kayrak-Talay, D., Akman, U., Hortaçsu, Ö., A review of ionic liquids towards supercritical fluid applications, J. Supercrit. Fluids 43 (2007) 150. doi: https://doi.org/10.1016/j.supflu.2007.05.013 
13. de los Ríos, A. P., Hernández-Fernández, F. J., Rubio, M., Tomás-Alonso Gómez, D., Villora, G., Prediction of the selectivity in the recovery of transesterification reaction products using supported liquid membranes based on ionic liquids, J. Membr. Sci. 307 (2008) 225. doi: https://doi.org/10.1016/j.memsci.2007.09.019

14. de los Ríos, A. P., Hernández-Fernández, F. J., Rubio, M., Tomás-Alonso, F., Gómez, D., Villora, G., On the importance of the nature of the ionic liquids in the selective simultaneous separation of the substrates and products of a transesterification reaction through supported ionic liquid membranes, J. Membr. Sci. 307 (2008) 225. doi: https://doi.org/10.1016/j.memsci.2007.09.019

15. Dai, Z., Richard, D. N., Douglas, L. G., Zhang, X., Deng, L., Combination of ionic liquids with membrane technology: A new approach for $\mathrm{CO}_{2}$ separation, J. Membr. Sci. 497 (2016) 1 doi: https://doi.org/10.1016/j.memsci.2015.08.060

16. Huang, K., Zhang, X. M., Li, Y. X., Wu, Y. T., Hu, X. B., Facilitated separation of $\mathrm{CO}_{2}$ and $\mathrm{SO}_{2}$ through supported liquid membranes using carboxylate-based ionic liquids, J. Membr. Sci. 471 (2014) 227. doi: https://doi.org/10.1016/j.memsci.2014.08.022

17. Lu, J. G., Lu, Z. Y., Chen, Y., Wang, J. T., Gao, L., Gao, X. Tang, Y. Q., Liu, D. G., $\mathrm{CO}_{2}$ absorption into aqueous blends of ionic liquid and amine in a membrane contactor, Sep. Purif. Technol. 150 (2015) 278.

doi: https://doi.org/10.1016/j.seppur.2015.07.010

18. Bates, E. D., Mayton, R. D., Ntai, I., Davis, J. H., $\mathrm{CO}_{2}$ capture by a task-specific ionic liquid, J. Am. Chem. Soc. 124 (2002) 926. doi: https://doi.org/10.1021/ja017593d

19. Scovazzo, P., Kieft, J., Finan, D. A., Koval, C., DuBois, D., Noble, R., Gas separations using non-hexafluorophosphate $\left[\mathrm{PF}_{6}\right]^{-}$anion supported ionic liquid membranes, J. Membr. Sci. 238 (2004) 57. doi: https://doi.org/10.1016/j.memsci.2004.02.033

20. Gomez-Coma, L., Garea, A., Rouch, J. C., Savart, T., Lahitte, J. F., Remigy, J. C., Irabien, A., Membrane modules for $\mathrm{CO}_{2}$ capture based on PVDF hollow fibers with ionic liquids immobilized, J. Membr. Sci. 498 (2015) 218. doi: https://doi.org/10.1016/j.memsci.2015.10.023

21. Tomé, L. C., Gouveia, A. S. L., Freire, C. S. R., Mecerreyes, D., Marrucho, I. M., Polymeric ionic liquid-based membranes: Influence of polycation variation on gas transport and $\mathrm{CO}_{2}$ selectivity properties, J. Membr. Sci. 486 (2015) 40. doi: https://doi.org/10.1016/j.memsci.2015.03.026

22. Santos, E., Albo, J., Irabien, A., Acetate based supported ionic liquid membranes (SILMs) for $\mathrm{CO}_{2}$ separation: Influence of the temperature, J. Membr. Sci. 452 (2014) 277. doi: https://doi.org/10.1016/j.memsci.2013.10.024

23. Barghi, S. H., Tsotsis, T. T., Sahimi, M., Solubility and diffusivity of $\mathrm{H}_{2}$ and $\mathrm{CO}_{2}$ in the ionic liquid [bmim] $\left[\mathrm{PF}_{6}\right.$ ], Int. J. Hydrogen Energy 40 (2015) 8713.

doi: https://doi.org/10.1016/j.ijhydene.2015.05.037

24. Ilconich, J., Myers, C., Pennline, H., Luebke, D., Experimental investigation of the permeability and selectivity of supported ionic liquid membranes for $\mathrm{CO}_{2} / \mathrm{He}$ separation at temperatures up to $125^{\circ} \mathrm{C}$, J. Membr. Sci. 298 (2007) 41. doi: https://doi.org/10.1016/j.memsci.2007.03.056

25. Hanioka, S., Maruyama, T., Sotani, T., Teramoto, M., Matsuyama, H., Nakashima, K., Hanaki, M., Kubota, F., Goto, $M$., $\mathrm{CO}_{2}$ separation facilitated by task-specific ionic liquids using a supported liquid membrane, J. Membr. Sci. 314 (2008) 1.

doi: https://doi.org/10.1016/j.memsci.2008.01.029
26. Gan, Q., Rooney, D., Xue, M., Thompson, G., Zou, Y., An experimental study of gas transport and separation properties of ionic liquids supported on nanofiltration membranes, J. Membr. Sci. 280 (2006) 948.

doi: https://doi.org/10.1016/j.memsci.2006.03.015

27. Morgan, D., Ferguson, L., Scovazzo, P., Diffusivities of gas in room-temperature ionic liquids: Data and correlations obtained using a lag-time technique, Ind. Eng. Chem. Res. 44 (2005) 4815.

doi: https://doi.org/10.1021/ie048825v

28. Jiang, Y. Y., Zhou, Z., Jiao, Z., Li, L., Wu, Y. T., Zhang, Z. $B$., $\mathrm{SO}_{2}$ gas separation using supported ionic liquid membranes, J. Phys. Chem. B 111 (2007) 5058. doi: https://doi.org/10.1021/jp071742i

29. Luis, P., Neves L. A., Afonso, C. A. M., Coelhoso, I. M., Crespo, J. G., Garea, A., Irabien, A., Facilitated transport of $\mathrm{CO}_{2}$ and $\mathrm{SO}_{2}$ through supported ionic liquid membranes (SILMs), Desalination 245 (2009) 485. doi: https://doi.org/10.1016/j.desal.2009.02.012

30. Scovazzo, P., Determination of the upper limits, benchmarks, and critical properties for gas separations using stabilized room temperature ionic liquid membranes (SILMs) for the purpose of guiding future research, J. Membr. Sci. 343 (2009) 199. doi: https://doi.org/10.1016/j.memsci.2009.07.028

31. Neves, L. A., Crespo, J. G., Coelhoso I. M., Gas permeation studies in supported ionic liquid membranes, J. Membr. Sci. 357 (2010) 160. doi: https://doi.org/10.1016/j.memsci.2010.04.016

32. Mannan, H. A., Mohshim, D. F., Mukhtar H., Murugesan, T., Man, Z., Bustam, M. A., Synthesis, characterization, and $\mathrm{CO}_{2}$ separation performance of polyether sulfone/ [EMIM] [Tf2N] ionic liquid-polymeric membranes (ILPMs), J. Ind. Eng. Chem. 54 (2017) 98. doi: https://doi.org/10.1016/j.jiec.2017.05.022

33. Reza, H., Navid, M., Arzani, A., Mohammadi, T., Improved $\mathrm{CO}_{2} / \mathrm{CH}_{4}$ separation using a nanocomposite ionic liquid gel membrane, J. Nat. Gas Sci. Eng. 46 (2017) 275. doi: https://doi.org/10.1016/j.jngse.2017.07.024

34. Ito, A., Yasuda, T., Ma, X., Watanabe, M., Sulfonated polyimide/ionic liquid composite membranes for carbon dioxide separation, Polymer J. 49 (2017) 671. doi: https://doi.org/10.1038/pj.2017.31

35. Friess, K., Lanč, M., Pilnáček, K., Fíla, V., Vopička, O., Sedláková, Z., Cowan, M. G., McDanel, W. M., Noble, R. D., Gin, D. L., Izak, P., $\mathrm{CO}_{2} / \mathrm{CH}_{4}$ separation performance of ionic-liquid-based epoxy-amine ion gel membranes under mixed feed conditions relevant to biogas processing, J. Membr. Sci. 528 (2017) 64. doi: https://doi.org/10.1016/j.memsci.2017.01.016

36. He, W., Zhang, F., Wang, Z., Sun, W., Zhou, Z., Ren, Z., Facilitated separation of $\mathrm{CO}_{2}$ by liquid membranes and composite membranes with task-specific ionic liquids, Ind. Eng. Chem. Res. 55 (2016) 12616. doi: https://doi.org/10.1021/acs.iecr.6b02778

37. Alkhouzaam, A., Khraisheh, M. A. M., Atilhan, M., Rooney D., High-pressure $\mathrm{CO}_{2} / \mathrm{N}_{2}$ and $\mathrm{CO}_{2} / \mathrm{CH}_{4}$ separation using dense polysulfone-supported ionic liquid membranes, J. Nat. Gas Sci. Eng. 36 (2016) 472. doi: https://doi.org/10.1016/j.jngse.2016.10.061

38. Hou, Q., Ju, M., Li, W., Liu, L., Chen, Y., Yang, Q., Pretreatment of lignocellulosic biomass with ionic liquids and ionic liquid-based solvent systems, Molecules 22 (2017) 490. doi: https://doi.org/10.3390/molecules 22030490 